\title{
Interlinkages in the Tunica Media of Goat Aorta
}

\author{
Interrelaciones en la Túnica Media de la aorta de Cabra
}

Julius Ogeng'o; Adel Abdel Malek \& Stephen Kiama

OGENG'O, J.; MALEK, A. A. \& KIAMA, S. Interlinkages in the tunica media of goat aorta. Int. J. Morphol., 28(2):409-414, 2010.

SUMMARY: The arrangement and interconnections between various components of the aortic wall influence its physicomechanical properties and functional alterations that occur in disease and ageing. The goat is a suitable model for studying cardiovascular disease, but details of the intrinsic organization of its aorta are unknown. This study therefore investigated the histomorphology of aortic tunica media in the goat by transmission electron microscopy. Sixteen healthy juvenile and adult domestic male goats (capra hircus) purchased from livestock farms in the outskirts of Nairobi were used in the study. The animals were euthanized with overdose of sodium pentabarbitone $20 \mathrm{mg} / \mathrm{kg}$, and fixed with $3 \%$ phosphate buffered glutaraldehyde solution by gravimetric perfusion. Specimens obtained from the thoracic aorta (T9) were post fixed in osmium tetroxide, and prepared for durcupan embedding. Ultrathin sections stained with uranyl acetate/lead citrate were examined by EM 201 Phillips (C) electron microscope. Elastic and collagen fibres were structurally interconnected. Elastic lamellae, collagen and elastic fibres were linked to smooth muscle cells through areas of high electron density while smooth muscle cells were interconnected various inter cellular connections. The physical interlinkages between the components of the tunica media confer plasticity, adaptability and flexibility to the aortic wall enabling it to function as a mechanically homogenous structure. Disruptions of this structure in atherosclerosis and aging may disturb the vascular integrity and predispose to aneurysm formation.

KEY WORDS: Matrix; Smooth muscle; Interlinkage; Aorta; Goat.

\section{INTRODUCTION}

Physical interlinkages between components of the tunica media are important in maintaining structural integrity and physicomechanical properties of the aortic wall (Dingemans et al., 2000; Silver \& Siperko, 2003). This in turn ensures efficient function of the aorta in dampening out pulsatile flow and blood pressure delivered by the heart, thus limiting distal shear stress and allowing regular irrigation of peripheral organs (Faury, 2001). Disruptions of these linkages are implicated in diseases processes such as atherosclerosis (Lavezzi et al., 2005) aneurysm formation (Hayashi et al., 2009) and in ageing (Greenwald, 2007). Details of the arrangement and interconnections between the components of matrix and cell-matrix linkages have remained elusive (Snowhill et $a l ., 2004)$. The goat is a suitable model for cardiovascular research but descriptions of the tunica media of its aorta are scarce. This study aimed at ellucidating the ultrastructure of tunica media in goat aorta.

\section{MATERIAL AND METHOD}

Sixteen juvenile and young adult male domestic goats (Capra hircus) aged 6-24 months were used in this study. Animals were purchased from livestock farmers in the outskirts of Nairobi, and only those certified by a veterinary doctor to be free of cardiovascular disease were included. They were euthanized with overdose of sodium pentabarbitone $20 \mathrm{mg} / \mathrm{ml}$ injected intravenously. They were opened through a midline incision and pericardium slit to expose the heart. Blood was removed by introducing normal saline through the left ventricle and draining it out through a slit in the right auricle. They were then fixed with $3 \%$ phosphate buffered glutaraldehyde solution by gravimetric perfusion. The lungs were retracted, and fat and connective tissue cleaned off to expose the descending thoracic aorta.

Specimens were taken from the middle of descending aorta at the level of 9th thoracic vertebra, and post fixed in 
phosphate buffered osmium tetroxide, dehydrated in ascending grades of ethanol, cleared in propylene oxide embedded in $100 \%$ durcupan with catalyst and polymerized in an oven at $60^{\circ} \mathrm{C}$, for 48 hours. Ultrathin sections made with Reichert ultramicrotome $\odot$ were collected on 200 mesh copper grids, stained with uranyl acetate, counterstained with elad citrate and examined by EM 201 Phillips@ electron microscope.

\section{RESULTS}

Tunica media of goat aorta consists of regular concentric elastic lamellae, between which are smooth muscle cells, collagen and elastic fibres. In the proximal segments down to T9, some of the elastic lamellae in the

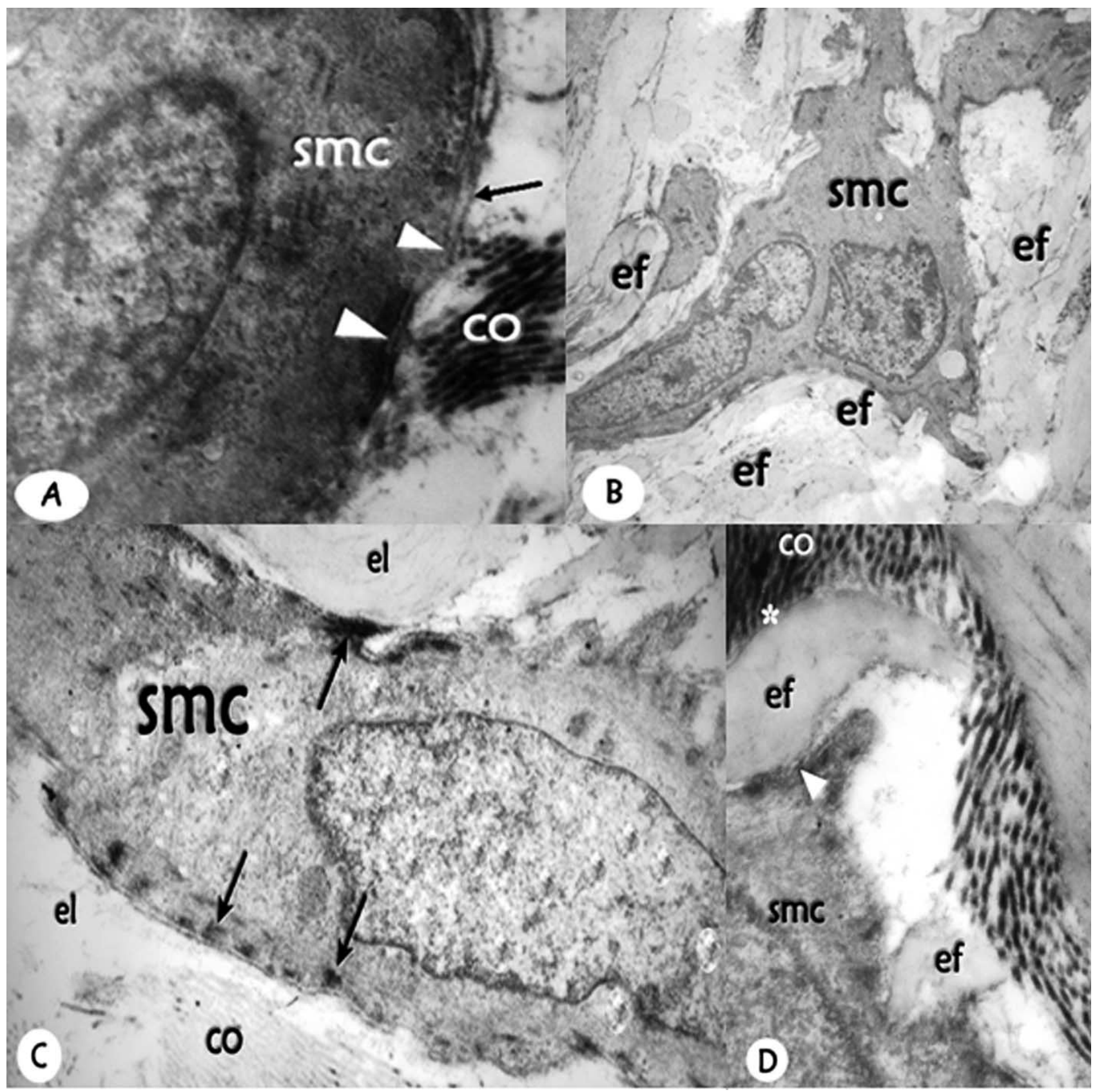

Fig. 1. A-D: Electron micrographs showing cell-matrix linkages in the tunica media of goat aorta. A. A smooth muscle cell (smc) with collagen (co) intimately linked to it through the basal lamina (arrow). Note areas of high electron density at those sites (arrowhead). x63,400. B. Smooth muscle cell (smc) with elastic fibres (ef) linked to it. x8,760. C. Smooth muscle cell (smc) with peripheral electron dense plaques (arrows) associated with attachment of elastic lamella (el), and collagen (co). x27,800. D. Linkage between collagen (co) and elastic fibre (ef) (star) and between elastic fibre(ef) and smooth muscle cell (smc) (arrowhead). x27.800. 
adventitial zone are interrupted by islands of smooth muscle. Collagen and elastic fibres anchor onto the surface of smooth muscle cells at various points (Fig. 1A-D). Where collagen inserts, the basal lamina is prominent and together with the cell surface shows high electron density (Fig. 1A), while where the elastic lamellae and fibres attach, the basal lamina is relatively less distinct (Fig. 1B,C). Occasionally, smooth muscle cells, collagen and elastic fibres are all physically interlinked (Fig. 1D). In the interlamellar spaces, collagen and elastic fibres are intimately associated (Fig. 2 A-D). Collagen fibres complexedly interweave then insert onto the end of the elastic fibre through its external microfibrillar component (Fig. 2A), or form bundles which insert onto the ends of the elastic fibres (Fig. 2B). In other cases, the collagen fibres insert onto the side of the elastic lamella (Fig. 2C), surround the elastic lamella or fibre, and insert along its entire

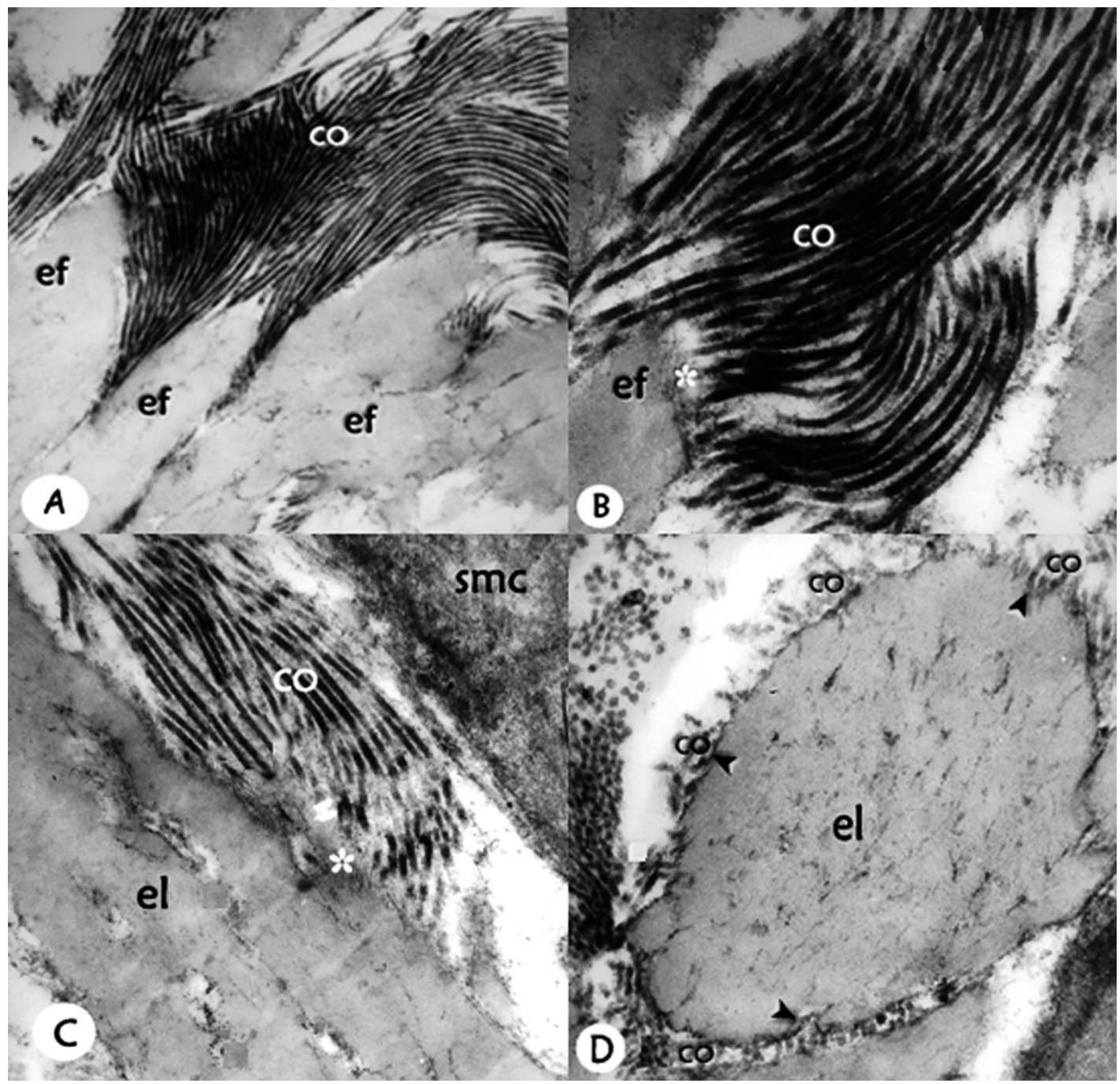

Fig. 2. A-D: Electron micrographs showing inter-linkages between collagen and elastin in the luminal zone of tunica media of goat thoracic aorta. A. A complex weave of collagen (co) inserting onto elastic fibres (ef). x27,800. B. A collagen bundle (co) inserting onto the elastic fibre (ef) through its peripheral microfibrillar mantle (star). x63,400. C. A parallel collagen bundle (co) turning to insert onto the side of an elastic lamella (el) through its peripheral microfibrillar mantle (star). Note smooth muscle cell (smc) in the neighbourhood. x63,400. D.A transverse elastic lamella (el), surrounded by collagen fibres (co) which attach onto its peripheral microfibrillar mantle (arrowheads). x63.400. 
circumference also through the peripheral microfibrillar component (Fig. 2D).

In many cases, smooth muscle cells display cytoplasmic extensions, where they come into contact with each other. At these sites, the cell processes interlock with each other (Fig. $3 \mathrm{~A})$ and in some of them, the basal laminae of the cells fuse (Fig. 3B). In others, the processes establish cytoplasmic continuity in a manner akin to gap junctions (Fig. 3C).

\section{DISCUSSION}

Observations of the present study reveal that both elastic lamellae and elastic fibres are structurally linked to smooth muscle cells through electron dense areas. Similar physical linkages have been reported in the aorta of other mammals (Clark \& Glagov, 1979; Dingemans et al., 1981), including spontaneously hypertensive rats (Bezie et al., 1998, 1999). Functionally, these cell to elastic fibre attachments modulate elasticity and extensibility of the tunica media, (Clark \& Glagov, 1979; Knox, 1981).

Collagen fibres in the goat aortic tunica media appear to insert onto the surface of smooth muscle cells through the basal lamina and subsarcolemal regions of high electron density. Previous in vivo studies did not demonstrate such insertions in the aorta (Clark \& Glagov, 1979, 1985; Dingemans et al., 1981; 2000). In vitro studies have, however, demonstrated that bovine aortic tunica media smooth muscle cells may attach to collagen (Grotendorst et al., 1981; Tosseli et al., 1984; Kielty et al., 1992). In their model of the vascular wall, Snowhill et al. depicted collagen fibres connected to integrins on the smooth muscle cell surface. In other arteries, collagen to smooth muscle cell contacts have been described whereby collagen fibres were partially placed in series with the intracellular myofilaments at the specialized sarcolemmal dark areas (Kimani, 1981; Komuro et al., 1982). These matrixcell linkages could have an important role in adapting the vessel to haemodynamic stress (Bezie et al., 1998, 1999) by increasing its mechanical strength.

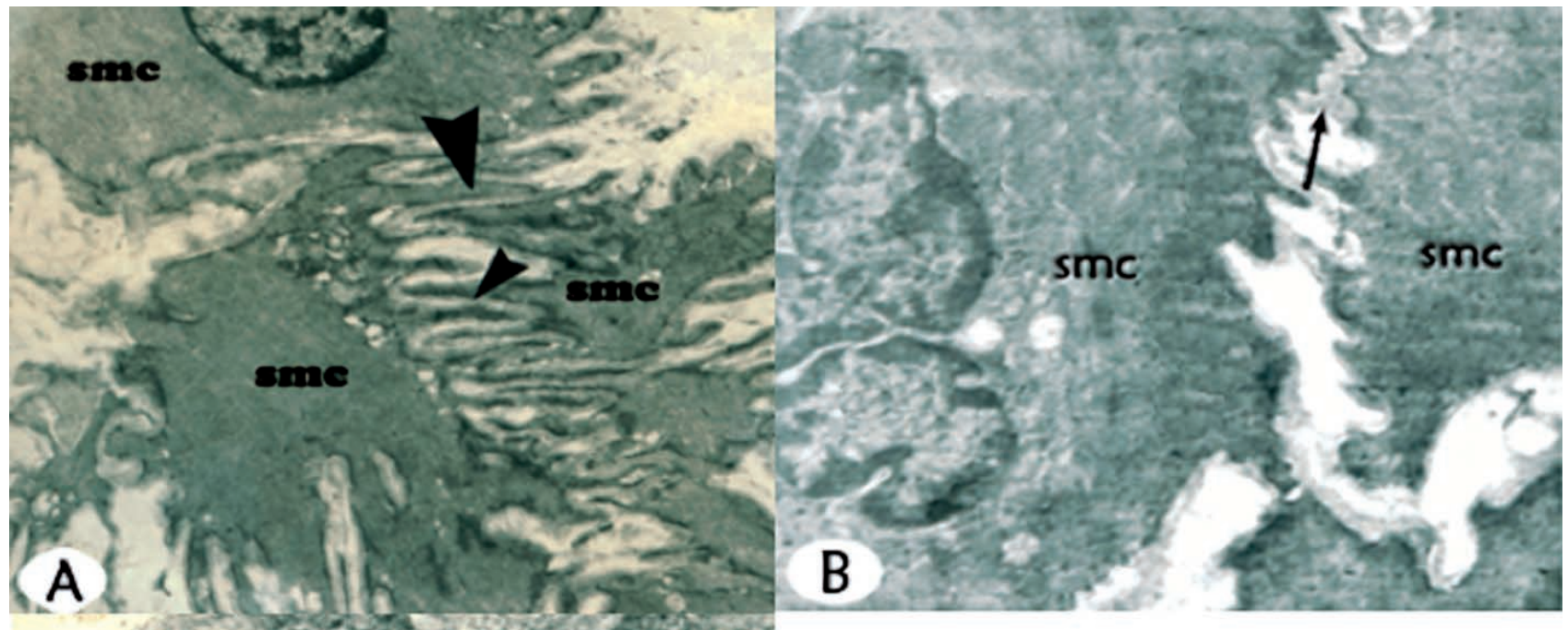

Fig. 3. A-C: Electron micrograph of smooth muscle cells in the tunica media of goat aorta. A. Extensive smooth muscle cell $(\mathrm{smc})$ interdigitations, characterized by high electron density (arrow heads). x27,800. B. Fusion of basal lamina (arrow) of the smooth muscles (smc). x27,800. C. Gap (arrow) and tight (arrowhead) junction-like union between smooth muscle cells $(\mathrm{smc})$ filled with myofilaments $(\mathrm{mf})$. x63.400. 
The present study further demonstrates that collagen and elastic fibres are intimately associated, and are in some cases structurally interlinked, as they are in other arteries (Kimani, 1993). Previous ultrastructural studies on the aorta of several mammals did not make reference to such linkages (Clark \& Glagov, 1979; 1985; Dingemans et al., 1981; 2000; Orsi et al., 2004, Farand et al., 2007). Some workers explicitly denied the existence of these linkages in the aortic wall (Gosline \& Shadwick, 1996; Shadwick, 1999). Snowhill et al., however, inferred that there appeared to be connections between collagen and elastic fibres. The view generally held is that close association of collagen and elastic fibres in the aortic wall provides the anatomical basis for functioning of tunica media in a biphasic manner (Mcveigh et al., 2002; Silver \& Siperko, 2003). In this arrangement, it is thought that below physiological pressures, the strain is born by elastic fibres of long range reversible stretchability (Kielty et al., 2002). At and above physiological pressure, the strain is taken up by collagen which has greater strength and resists stretch (Shadwick). It is conceivable, therefore, that the structural intimacy demonstrated in the present study is designed to confer higher mechanical strength to the aorta, while at the same time enabling it to function in the biphasic fashion.

Smooth muscle cells in the tunica media of the goat thoracic aorta, and especially in the muscle islands of the adventitial zone, interdigitate and frequently form junctions with each other. This supports reports on the existence of simple appositions characterized by folds, invaginations and projections, zonulae occludentes and gap junctions (Litwin, 1980; Sosa-Melgarejo et al., 1991). These cellular interdigitations, may be areas of close intercellular apposition which represent various junctional structures, designed to provide both electrotonic and mechanical coupling between the cells.

The interlocked structure of elastin, muscle and collagen may confer plasticity, adaptability and flexibility to the aortic tunica media (Christ et al., 1996) enabling it to function as a mechanically homogenous structure (Dobrin, 1999). The linkage between the structural components in the tunica media could also play a physiological role, leading to the maintenance of physicomechanical homeostasis.

In conclusion, the physical interlinkages between the components of the tunica media confer plasticity, adaptability and flexibility to the aortic wall enabling it to function as a mechanically homogenous structure. Disruptions of those structure in atherosclerosis and aging may disturb vascular integrity and predispose to aneurysm formation.

\section{ACKNOWLEDGEMENT}

We wish to thank James Macharia, Jackson Gachoka, Christopher Kamwaro for their invaluable technical support and Catherine Chinga for secretarial assistance. This work was part of $\mathrm{PhD}$ thesis of University of Nairobi.

OGENG'O, J.; MALEK, A. A. \& KIAMA, S. Interrelaciones en la túnica media de la aorta de cabra. Int. J. Morphol., 28(2):409-414, 2010.

RESUMEN: Los relaciones e interconexiones entre los distintos componentes de la pared aórtica influyen en sus propiedades fisicomecánicas y en las alteraciones funcionales que se producen en la enfermedad y el envejecimiento. La cabra es un modelo adecuado para el estudio de las enfermedades cardiovasculares, pero los detalles de la organización propia de la aorta son desconocidos. Por tanto, se investigó la histomorfología de la túnica media aórtica en la cabra mediante microscopía electrónica de transmisión. Fueron utilizadas 16 cabras (Capra hircus) domésticas macho, jóvenes y adultas sanas, adquiridas en las explotaciones ganaderas en las afueras de Nairobi fueron utilizadas. Los animales fueron sacrificados con una sobredosis de $20 \mathrm{mg} / \mathrm{kg}$ de pentobarbital sódico, y se fijaron con una solución de fosfato de glutaraldehído al 3\% por perfusión gravimétrica. Las muestras obtenidas de la aorta torácica (T9) fueron puestas en tetróxido de osmio, y se prepararon para inclusión en durcupan. Secciones ultrafinas teñidas con acetato de uranilo y citrato de plomo fueron examinados por microscopio electrónico EM 201 Phillips@. Fibras elásticas y colágenas estaban interconectadas estructuralmente. Láminas elásticas, de colágeno y fibras elásticas estaban conectadas a células de músculo liso a través de áreas de alta densidad de electrones, mientras que, las células musculares lisas estaban interconectados entre diferentes conexiones celulares. Las interconexiones físicas entre los componentes de la túnica media confieren plasticidad, adaptabilidad y flexibilidad a la pared aórtica, lo que le permite funcionar como una estructura mecánica homogénea. Las interrupciones de estas estructuras en la aterosclerosis y el envejecimiento pueden alterar la integridad vascular y predisponer a la formación de aneurismas.

PALABRAS CLAVE: Matriz; Músculo liso; Interrelación; Aorta; Cabra.

\section{REFERENCES}

Bezie, Y.; Daniel-Lamaziere, J. M.; Gabella, G.; Koffi, L.; Laurent, S. \& Lacolley, P. Molecular and cellular determinants of arterial stiffness: role of cell-matrix connections. Pathol. Biol. (Paris), 47: 669-76, 1999.
Bezie, Y.; Lacolley, P.; Laurent, S. \& Gabella, G. Connection of smooth muscle cells to elastic lamellae in aorta of spontaneously hypertensive rats. Hypertension, 32:166-9, 1998. 
Christ, G. J.; Spray, D. C.; El-Sabban, M.; Moore, L. K. \& Brink, P. R. Gap junctions in vascular tissues. Evaluating the role of intercellular communication in the modulation of vasomotor tone. Circ. Res., 79:631-46, 1996.

Clark, J. M. \& Glagov, S. Structural integration of the arterial wall. I. Relationship and attachments of medial smooth muscle cells in normally distended and hyperdistended aortas. Lab. Invest., 40:587-602, 1979.

Clark, J. M. \& Glagov, S. Transmural organization of the arterial wall. Arteriosclerosis, 5:19-34, 1985.

Dingemans, K. P.; Jansen, N. \& Becker, A. E. Ultrastructure of the normal human aortic media. Virchows Arch. A. Pathol. Anat. Histol., 392:199-216, 1981.

Dingemans, K. P.; Teeling, P.; Lagendijk, J. H. \& Becker, A. E. Extracellular matrix of the human aortic media: an ultrastructural histochemical and immunohistochemical study of the adult aortic media. Anat. Rec., 258:1-14, 2000.

Dobrin, P. B. Distribution of lamellar deformations. Implications for properties of the arterial media. Hypertension, 33:806-10, 1999.

Farand, P.; Garon, A. \& Plante, G. E. Structure of large arteries: orientation of elastin in rabbit internal elastic lamina, and in elastic lamellae of aortic media. Microvasc. Res., 73:95-9, 2007.

Faury, G. Function-structure relationship of elastic arteries in evolution: from microfibrils to elastin and elastic fibres. Pathol. Biol. (Paris), 49:310-25, 2001.

Gosline, J. M. \& Shadwick, R. E. The mechanical properties of fin whale arteries are explained by novel connective tissue design. J. Exp. Biol., 199:985-95, 1996.

Greenwald, S. E. Ageing of the conduit arteries. J. Path., 211:157-72, 2007.

Grotendorst, G. R.; Seppa, H. E. J.; Kleinman, H. K. \& Martin, G. R. Attachment of smooth muscle cell to collagen and their migration toward platelet-derived growth factor. Proc. Natl. Acad. Sci. U S A, 78:3669-72, 1981.

Hayashi, T.; Morishita, E.; Ohtake, H.; Oda, Y.; Asakura, H. \& Nakao, $\mathrm{S}$. Expression of annexin II in experimental abdominal aortic aneurysms. Int. J. Hematol., 90(3):336-42, 2009.

Kielty, C. M.; Sherratt, M. J. \& Shuttleworth, C. A. Elastic fibres. J. Cell Sci., 115(14):2817-28, 2002.

Kielty, C. M.; Whittaker, S. P.; Grant, M. E. \& Shuttleworth, C. A. Attachment of human vascular smooth muscle cell to intact microfibrillar assemblies of collagen VI and fibrillin. J. Cell Sci., 103:445-451, 1992.

Kimani, J. K. Structural Evidence for Insertion of Collagen fibres to Smooth Muscle cells in the carotid arterial dystem of the (Giraffa camelopardalis). Cell Tiss. Res. 214:219-24, 1981.

Kimani, J. K. Structural linkage between collagen and elastic fibres in the mammalian carotid sinus wall with special reference to baroreceptor mechanisms. Discovery and Innovation, 5:51-56, 1993.

Knox, P. Biochemistry of cellular regulation. Boca Raton, CRC Press, 1981. pp.122-49.

Komuro, T.; Desaki, Y. \& Euhara, Y. Three-dimensional organization of smooth muscle cells in blood vessels of laboratory rodents. Cell. Tiss. Res., 227:429-37, 1982.

Lavezzi, A. M.; Ottaviani, G. \& Matturri, L. Biology of the smooth muscles in human atherosclerosis. APMIS, 113(2):112-21, 2005.

Litwin, J. A. Cell membrane features of rabbit arterial smooth muscle. Cell Tiss. Res., 212:341-50, 1980.

McVeigh, G. E.; Hamilton, P. K. \& Morgan, D. R. Evaluation of mechanical arterial properties: clinical, experimental and therapeutic aspects. Clin. Sci. (Lond), 102(1):51-67, 2002.

Orsi, A. M.; Stefanini, M. A.; Crocci, A. J.; Simoes, K. \& Ribeiro, A. A. C. M. Some segmental features on the structure of the aortic wall of the dog. Anat. Histol. Embryol., 31:131-4, 2004.

Shadwick, R. E. Mechanical design in arteries. J. Exp. Biol., 202:330513, 1999.

Silver, F. H. \& Siperko, L. M. Mechanosensing and mechanochemical transduction: how is mechanical energy sensed and converted into chemical energy in an extracellular matrix? Crit. Rev. Biomed. Eng., 31:255-331, 2003.

Snowhill, P. B.; Foran, D. J. \& Silver, F. H. A Mechanical Model of Porcine Vascular Tissues-Part I: Determination of Macromolecular Component Arrangement and Volume Fractions. Cardiovasc Eng., 4:281-93, 2004.

Sosa-Melgarejo, J. A.; Berry, C. L. \& Robinson, N. A. Effects of hypertension on the intercellular contacts between smooth muscle cells in the rat thoracic aorta. J. Hypertens., 9:475-80, 1991.

Toselli, P.; Faris, B.; Oliver, P. \& Franzblau, C. Ultrastructure studies of attachment site formation in aortic smooth muscle cells cultured on collagen- Hydroxyethylmethacrylate hydrogels. J. Ultrastruct. Res., 86:252-61, 1984.

\section{Correspondence to: \\ Julius A. Ogeng'o \\ Department of Human Anatomy \\ University of Nairobi \\ P.O. Box $30197-00100$ \\ Nairobi \\ KENYA}

Email: jogengo@uonbi.ac.ke

Received: 14-10-2009

Accepted: 15-02-2010 